\title{
PERUBAHAN SIFAT KIMIA DAN POLA PELEPASAN AMONIUM DAN NITRAT PADA ULTISOL DARMAGA YANG DIBERI PUPUK PELET BERBAHAN DASAR LUMPUR KOLAM IKAN
}

\author{
Chemical Properties Changes and Releasing Pattern of Ammonium and \\ Nitrate on Ultisol Darmaga Fertilized by Fishpond Sediment-Based Pellet \\ Fertilizer
}

\author{
Arief Hartono ${ }^{1)^{*}}$, Lilik Tri Indriyati ${ }^{1)}$, Putri Tria Santari2) dan Neng Elin \\ Novianti ${ }^{3)}$ \\ 1) Departemen Ilmu Tanah dan Sumberdaya Lahan, Fakultas Pertanian, IPB University, Jl. Meranti \\ Kampus IPB Darmaga Bogor 16680 \\ 2) Program Studi Ilmu Tanah Sekolah Pascasarjana IPB University, Kampus IPB Darmaga Bogor 16680 \\ 3) Program Studi Manajemen Sumberdaya Lahan, IPB University, Kampus IPB Darmaga Bogor 16680
}

\begin{abstract}
Fishpond sediment-based pellet fertilizer enriched with fishpond water and goat manure was made to decrease load of nitrate contamination in water bodies. The objective of this research was to evaluate the changes of some soil chemical properties and the releasing pattern of nitrogen $(\mathrm{N})$-ammonium $\left(\mathrm{N}-\mathrm{NH}_{4}{ }^{+}\right)$and $\mathrm{N}$-nitrate $\left(\mathrm{N}-\mathrm{NO}_{3}^{-}\right)$in Ultisol Darmaga which was fertilized by pellet fertilizer. The rate of pellet fertilizer which was applied to the soil was $6.10 \mathrm{~g}$ of pellets/300 $\mathrm{g}$ of soil or equivalent to

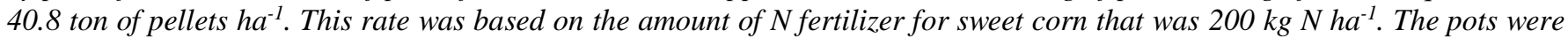
incubated in 1 week, 2 weeks, 3 weeks, 4 weeks, 5 weeks, 6 weeks, 7 weeks, 8 weeks, 10 weeks, and 15 weeks at field capacity condition. Soil analyses were conducted after the end of each incubation period. The results showed that in the end of incubation period, the application of pellet fertilizer increased soil $\mathrm{pH}$, organic carbon, cation exchange capacity, exchangeable bases, $\mathrm{N}-\mathrm{NH}_{4}{ }^{+}$, and $\mathrm{N}-\mathrm{NO}_{3}{ }^{-}$and total available $\mathrm{N}$ which is the total amount of $\mathrm{N}-\mathrm{NH}_{4}{ }^{+}$, and $\mathrm{N}-\mathrm{NO}_{3}{ }^{-}$compared to those of control soil. As for the releasing pattern of $\mathrm{N}-\mathrm{NH}_{4}{ }^{+}$and $\mathrm{N}-\mathrm{NO}_{3}{ }^{-}$, in the 1 week to 7 weeks of incubation $\mathrm{N}-\mathrm{NH}_{4}^{+}$was dominant and decreased after that. The decrease of $\mathrm{N}-\mathrm{NH}_{4}{ }^{+}$was followed by the increase of $\mathrm{N}-\mathrm{NO}_{3}{ }^{-}$. The $\mathrm{N}-\mathrm{NO}_{3}^{-}$was dominant from 8 weeks to 15 weeks of incubation. The results recommended that fishpond sediment-based pellet fertilizer improved the soil properties and provided available $N$.
\end{abstract}

Keywords: ammonium, chemical properties, nitrate, pellet fertilizer

\begin{abstract}
ABSTRAK
Pupuk pelet berbahan dasar lumpur kolam ikan yang diperkaya dengan air kolam ikan dan pupuk kandang kambing dibuat untuk mengurangi kontaminasi nitrat di badan-badan air. Tujuan dari penelitian ini adalah untuk mengevaluasi perubahan beberapa sifat kimia tanah dan pola pelepasan nitrogen $(\mathrm{N})$-amonium $\left(\mathrm{N}-\mathrm{NH}_{4}{ }^{+}\right)$dan $\mathrm{N}$-nitrat $\left(\mathrm{N}-\mathrm{NO}_{3}{ }^{-}\right)$pada Ultisol Darmaga yang diberi pupuk pelet. Dosis pupuk pelet yang diberikan ke dalam tanah adalah $6.10 \mathrm{~g}$ pelet $/ 300 \mathrm{~g}$ tanah atau setara dengan 40.8ton pellet $\mathrm{ha}^{-1}$. Dosis pupuk pelet yang diberikan didasarkan pada dosis pupuk $\mathrm{N}$ tanaman jagung manis yaitu sebesar 200 $\mathrm{kg} \mathrm{N} \mathrm{ha}{ }^{-1}$. Pot-pot percobaan tersebut diinkubasi selama 1 minggu, 2 minggu, 3 minggu, 4 minggu, 5 minggu, 6 minggu, 7 minggu, 8 minggu 10 minggu, dan 15 minggu pada kondisi kapasitas lapang. Analisis tanah dilakukan pada setiap akhir masa inkubasi. Hasil penelitian menunjukkan bahwa aplikasi pupuk pelet meningkatkan $\mathrm{pH}$ tanah, karbon organik, kapasitas tukar kation, basa-basa dapat dipertukarkan, $\mathrm{N}_{-} \mathrm{NH}_{4}{ }^{+}$and $\mathrm{N}-\mathrm{NO}_{3}{ }^{-}$dan total $\mathrm{N}$-tersedia yang merupakan penjumlahan $\mathrm{N}-\mathrm{NH}_{4}{ }^{+}$and $\mathrm{N}-$ $\mathrm{NO}_{3}{ }^{-}$. Untuk pola pelepasan $\mathrm{N}_{-} \mathrm{NH}_{4}{ }^{+}$, dan $\mathrm{N}_{-} \mathrm{NO}_{3}{ }^{-}$, pada minggu 1 sampai minggu $7, \mathrm{~N}_{-} \mathrm{NH}_{4}{ }^{+}$adalah bentuk $\mathrm{N}$ tersedia yang dominan akan tetapi menurun setelah itu. Penurunan $\mathrm{N}-\mathrm{NH}_{4}{ }^{+}$diikuti oleh kenaikan $\mathrm{N}_{-} \mathrm{NO}_{3}{ }^{-}$. Pada minggu 8 sampai minggu 15 , $\mathrm{N}^{-} \mathrm{NO}_{3}{ }^{-}$adalah bentuk $\mathrm{N}$ tersedia yang paling dominan. Hasil penelitian merekomendasikan bahwa pupuk pelet berbahan dasar lumpur kolam ikan memperbaiki sifat tanah dan menyediakan $\mathrm{N}$ yang tersedia.
\end{abstract}

Kata kunci: amonium sifat kimia, nitrat, pupuk pelet,

\section{PENDAHULUAN}

Desa Petir merupakan salah satu desa yang berada di daerah hulu yang terletak di lereng kaki Gunung Salak, Kecamatan Darmaga, Kabupaten Bogor. Desa Petir memiliki potensi pertanian terpadu yaitu pertanian, perikanan, dan peternakan. Kegiatan pertanian di Desa Petir sangat intensif, salah satunya adalah budidaya ikan air tawar dan memiliki pekerjaan sampingan sebagai peternak kambing. Kegiatan pertanian ini tentunya menghasilkan limbah yaitu berupa lumpur dan air kolam ikan serta kotoran kambing. Petani biasanya memanfaatkan lumpur 
kolam ikan sebagai penguat batas kolam, air kolam ikan dibuang ke parit-parit dan kotoran kambing digunakan langsung sebagai pupuk organik. Air yang dibuang ke paritparit kemudian mengalir ke sungai-sungai yang akhirnya bermuara di Teluk Jakarta. Pembuangan air kolam ikan ini dapat menjadi salah satu penyumbang tinggimya kadar nitrat dan fosfat di perairan Teluk Jakarta. Tingginya kadar nitrat dan fosfat di Teluk Jakarta dapat memicu terjadinya ledakan populasi fitoplankton atau alga, sehingga yang terjadi adalah kematian ikan dalam jumlah besar akibat kekurangan oksigen untuk berespirasi (Tungka et al., 2016). Oleh karena itu, untuk mengurangi limbah pertanian yang terdapat di desa Petir, perlu adanya upaya pemanfaatan limbah menjadi suatu pupuk yang tepat guna.

Menurut penelitian terdahulu yang dilakukan oleh Hartono et al. (2012) menyatakan bahwa lumpur dan air kolam ikan di Desa Petir sangat potensial untuk dijadikan pupuk karena mengandung hara-hara yang dibutuhkan oleh tanaman. Lumpur dan air kolam ikan di Desa Petir mengandung banyak nitrogen $(\mathrm{N})$, fosfor $(\mathrm{P})$, karbon organik (C-organik), dan kation-kation basa ( $\mathrm{Ca}, \mathrm{Mg}, \mathrm{K}$, dan $\mathrm{Na}$ ). Pemberian kombinasi lumpur kolam ikan dan air kolam juga meningkatkan produksi ubi di desa Petir, Darmaga, Bogor (Hartono et al., 2016).

Walaupun demikian pemanfaatan lumpur dan air kolam ikan juga kotoran kambing dalam bentuk aslinya memerlukan tempat yang luas dalam penyimpanan dan mudah hanyut kembali oleh air hujan. Oleh karena itu upaya untuk membuat bahan-bahan tersebut dapat disimpan dengan mudah dan dapat bertahan lama adalah dengan membuat pupuk pelet.

Tujuan dari penelitian ini adalah mengevaluasi pengaruh pemberian pupuk pelet berbahan dasar lumpur kolam ikan yang diperkaya dengan air kolam ikan dan pupuk kandang (pukan) kambing terhadap beberapa sifat kimia tanah dan mengevaluasi pola pelepasan $\mathrm{N}$-amonium $\left(\mathrm{N}-\mathrm{NH}_{4}{ }^{+}\right)$dan $\mathrm{N}$-nitrat $\left(\mathrm{N}-\mathrm{NO}_{3}{ }^{-}\right)$.

\section{BAHAN DAN METODE}

Penelitian ini dilakukan pada bulan November 2016 sampai bulan Juli 2017. Analisis sifat kimia tanah dilakukan di Laboratorium Kimia dan Kesuburan Tanah, Departemen Ilmu Tanah dan Sumberdaya Lahan, Fakultas Pertanian, Institut Pertanian Bogor. Bahan yang digunakan dalam penelitian ini yaitu contoh tanah Ultisol Dramaga, Bogor yang diambil secara komposit dari kedalaman 0 - 20 cm dan pupuk pelet dengan bahan dasar lumpur kolam ikan yang diperkaya dengan air kolam ikan dan pupuk kandang kambing. Bahan kimia yang digunakan adalah bahan-bahan kimia yang terkait dengan analisis $\mathrm{pH}, \mathrm{N}$-total, C-organik, kapasitas tukar kation (KTK), basa-basa yang dapat dipertukarkan, $\mathrm{N}-\mathrm{NH}_{4}{ }^{+}$, dan $\mathrm{N}-\mathrm{NO}_{3}{ }^{-}$. Alat yang digunakan yaitu wadah plastik, botol semprot, timbangan, dan peralatan lain di laboratorium.

Pupuk pelet dibuat dari lumpur kolam ikan, pukan kambing, air kolam ikan dan tepung kanji. Pukan kambing, lumpur kolam ikan dan air kolam ikan diambil di desa Petir, Darmaga, Bogor. Pukan kambing yang sudah dalam bentuk kering diayak dengan ayakan $2 \mathrm{~mm}$. Lumpur kolam ikan dikeringudarakan dalam oven pada suhu $70{ }^{\circ} \mathrm{C}$ selama 48 jam kemudian ditumbuk dan diayak dengan ayakan $2 \mathrm{~mm}$. Komposisi campuran untuk membuat pupuk pelet adalah 500 gram lumpur kolam ikan, 500 gram kotoran kambing, 30 gram tepung kanji, dan $500 \mathrm{ml}$ air kolam ikan lalu semua bahan dimasukkan ke dalam wadah ember plastik dan diaduk secara merata. Campuran dimasukkan dalam mesin pembuat pelet seperti pada Gambar 1. Pupuk pelet dianalisis untuk mendapatkan data $\mathrm{pH}$, kandungan N-total, kandungan P-total, kandungan K-total dan kadar C-organik. $\mathrm{pH} \mathrm{H}_{2} \mathrm{O}$ (1:5) diukur menggunakan $\mathrm{pH}$ meter, $\mathrm{N}$-total pelet ditetapkan menggunakan metode Kjeldahl, P-total dan Ktotal ditetapkan dengan metode pengabuan basah yaitu destruksi menggunakan asam nitrat pekat dan asam perklorat pekat dan C-organik ditetapkan dengan menggunakan metode Gravimetri berdasarkan kehilangan berat. Hasil analisis disajikan pada Tabel 1.

Tabel 1. Hasil analisis pupuk pelet

\begin{tabular}{lcr}
\hline \multicolumn{1}{c}{ Sifat kimia } & Satuan & Nilai \\
\hline $\mathrm{pH}$ & & 7.10 \\
N-Total & $\%$ & 0.50 \\
P-Total & $\%$ & 0.17 \\
K-Total & $\%$ & 0.41 \\
C-organik & $\%$ & 12.1 \\
\hline
\end{tabular}

Percobaan inkubasi dilakukan dengan menyiapkan tanah yang telah dikeringudarakan dan diayak lolos saringan 2-mm, kemudian digunakan tanah sebanyak $316 \mathrm{~g}$ bobot kering udara atau setara dengan $300 \mathrm{~g}$ bobot kering mutlak. Dosis pupuk pelet yang diberikan ke dalam tanah adalah $6.10 \mathrm{~g}$ pelet $300 \mathrm{~g}^{-1}$ tanah atau setara dengan 40.8ton pellet ha ${ }^{-1}$ dengan kandungan $\mathrm{N}$ pada pelet sebesar $0.5 \%$. Percobaan inkubasi ini memiliki dua perlakuan yaitu tanah tanpa perlakuan (kontrol) dan tanah yang diberi aplikasi pupuk pelet (pelet) yang masing-masing perlakuan diulang sebanyak tiga kali. Dosis pupuk pelet yang diberikan didasarkan pada dosis pupuk $\mathrm{N}$ tanaman jagung manis yaitu sebesar $200 \mathrm{~kg} \mathrm{~N} \mathrm{ha}{ }^{-1}$. Pada tanah yang dibei perlakuan pelet, pupuk pelet dicampur secara merata dengan tanah lembab disetiap wadah plastik. Tanah ini kemudian diinkubasi pada suhu kamar selama 1 minggu, 2 minggu, 3 minggu, 4 minggu, 5 minggu, 6 minggu, 7 minggu, 8 minggu, 10 minggu dan 15 minggu. Kadar air tanah selama masa percobaan dipertahankan pada kadar air kapasitas lapang.

Analisis sifat kimia tanah ditetapkan pada minggu ke-1, 2, 3, 4, 5, 6, 7, 8, 10 dan 15 masa inkubasi. Sifat kimia tanah yang dianalisis meliputi, C-organik dengan menggunakan metode Wakley and Black, KTK dan basabasa yang dapat dipertukarkan dengan menggunakan $\mathrm{NH}_{4} \mathrm{OAc} 1.00 M \mathrm{pH}$ 7.00. $\mathrm{N}_{-} \mathrm{NH}_{4}{ }^{+}$dan $\mathrm{N}^{-\mathrm{NO}_{3}}{ }^{-}$tanah diekstraksi menggunakan campuran $\mathrm{KCl} 1 \mathrm{~N}$ dan $\mathrm{HCl} 0,1$ $N$. N-NH${ }_{4}{ }^{+}$ditetapkan menggunakan metode Kjeldhal dan $\mathrm{N}-\mathrm{NO}_{3}{ }^{-}$diukur dengan menggunakan UV-spektrofotometer dengan panjang gelombang $210 \mathrm{~nm}$ dan dikoreksi oleh panjang gelombang $275 \mathrm{~nm}$ dengan faktor koreksi 2.5 (Widowati et al., 2011) menggunakan tanah lembab dan $\mathrm{pH}$ $\mathrm{H}_{2} \mathrm{O}$ (1:5) ditetapkan menggunakan $\mathrm{pH}$ meter. Data hasil analisis disajikan dalam bentuk deskriptif. 


\section{HASIL DAN PEMBAHASAN}

\section{Perubahan Beberapa Sifat Kimia Tanah Setelah Perlakuan Pupuk Pelet}

\section{pH Tanah}

Perlakuan pupuk pelet meningkatkan $\mathrm{pH}$ tanah pada setiap masa inkubasi dibandingkan dengan kontrol (Gambar 2). Peningkatan $\mathrm{pH}$ tanah karena pemberian pupuk pelet tidak terlalu besar dibandingkan dengan $\mathrm{pH}$ tanah kontrol. Perubahan $\mathrm{pH}$ karena pemberian pupuk pelet diduga adanya pengikatan aluminium yang dapat dipertukarkan (Al-dd) oleh bahan organik membentuk senyawa organometallic. Hal ini mungkin terjadi karena Pupuk pelet mengandung C-organik 12.1\% (Tabel 1).

Pada akhir inkubasi yaitu minggu $15 \mathrm{pH}$ tanah berubah dari 4.05 menjadi 4.39. Perubahan $\mathrm{pH}$ tanah yang tidak terlalu besar karena tanah yang digunakan dalam penelitian ini Ultisol Darmaga yang mempunyai Al-dd sebesar $21.4 \mathrm{cmol}_{\mathrm{c}} \mathrm{kg}^{-1}$ (Santari et al., 2019). Kandungan Al-dd yang besar tersebut mempunyai daya sangga tanah yang besar sehingga perubahan $\mathrm{pH}$ tanah karena perlakuan pupuk pelet tidak besar.

\section{C-organik}

Perubahan kadar C-organik tanah setelah pemberian pupuk pelet disajikan pada Gambar 3. C-organik tanah pada tanah yang diberi pupuk pelet di awal inkubasi sampai akhir inkubasi lebih tinggi dibandingkan dengan tanah kontrol. Hal ini karena pupuk pelet mengandung 12.1\% C-organik (Tabel 1). Tanah yang diperlakukan pupuk pelet meningkat kandungan C-organiknya sampai $3.53 \%$ pada minggu 4 , setelah itu menurun nilainya sampai minggu 15 sebagai akhir masa inkubasi. Pada minggu 15, kadar C-organiknya adalah $1.64 \%$. Penurunan tersebut dapat terjadi karena adanya reaksi oksidasi C-organik menjadi $\mathrm{CO}_{2}$ oleh mikroorganisme tanah sebagai akibat dari proses dekomposisi bahan organik (Escobar dan Hue, 2008). Menurut Roy dan Kashem (2014), penurunan kadar C-organik yang relatif cepat merupakan petunjuk dari tingginya kandungan fraksi organik labil (kurang resisten) yang dapat dirombak oleh mikroorganisme yang mengakibatkan kandungan C-organik pada akhir inkubasi menjadi lebih rendah. Fraksi yang temasuk ke dalam fraksi organik labil adalah fraksi larut air seperti gula sederhana, asam amino dan asam alifatik. Menurut (Follet et al., 2007;
Gulser et al., 2010; Roy dan Kashem, 2014) menyatakan bahwa pemberian bahan organik mampu meningkatkan kadar C-organik tanah pada masa awal-awal inkubasi dan menurun dengan bertambahnya waktu dan akhirnya menuju kesetimbangan.

Pola yang sama terjadi pada tanah kontrol dimana awal inkubasi terjadi peningkatan C-organik tanah pada awal inkubasi sampai minggu 4 dan menurun dimana pada akhir inkubasi nilainya mendekati nilai di awal inkubasi. Pada perlakuan kontrol mungkin kandungan fraksi organik labil hanya sedikit bahkan sudah didominasi oleh kandungan fraksi organik yang bersifat stabil sehingga tidak terjadi fluktuasi peningkatan dan penurunan kadar Corganik yang besar pada masa inkubasi (Gambar 3).

\section{Kapasitas Tukar Kation (KTK) Tanah}

KTK tanah meningkat pada setiap masa inkubasi pada perlakuan pupuk pelet dibandingkan dengan tanah kontrol (Gambar 4). Peningkatan ini karena meningkatnya C-organik tanah pada perlakuan pupuk pelet (Gambar 3). Peningkatan C-organik tanah akan meningkatkan muatan negatif tanah yang bergantung $\mathrm{pH}$ ( $\mathrm{pH}$ dependent charge) (Bohn et al., 1979). Nilai KTK ini mulai menurun pada minggu 6 dan pada akhir masa inkubasi yaitu pada minggu 15 nilai KTK tanah adalah $35.1 \mathrm{cmol}_{\mathrm{c}} \mathrm{kg}^{-1}$ sejalan dengan menurunya C-organik tanah.

Pada perlakuan kontrol nilai KTK mempunyai fluktuasi yang kecil dan cenderung tetap pada setiap masa inkubasi. Hal ini sesuai dengan perubahan C-organik yang juga mempunyai fluktuasi yang kecil (Gambar 3).

\section{Kalsium, Magnesium dan Kalium yang dapat dipertukarkan (Ca-dd, Mg-dd dan K-dd)}

Ca-dd, Mg-dd dan K-dd tanah yang diberi perlakuan pupuk pelet dan tanah tanpa pupuk pelet (kontrol) disajikan pada Gambar 5, 6 dan 7. Secara umum perlakuan pupuk pelet meningkatkan Ca-dd, Mg-dd dan K-dd dibandingkan dengan perlakuan kontrol.

Peningkatan $\mathrm{Ca}-\mathrm{dd}, \mathrm{Mg}$-dd dan $\mathrm{K}$-dd tanah diduga karena ada penambahan dari lumpur kolam ikan, pukan kambing dan air kolam ikan. Hartono et al. (2016) melaporkan bahwa lumpur kolam ikan yang diambil dari desa Petir mempunyai Ca-dd, Mg-dd dan K-dd yang sangat tinggi berdasarkan kriteria yang dipublikasi oleh Soepraptohardjo et al. (1983).
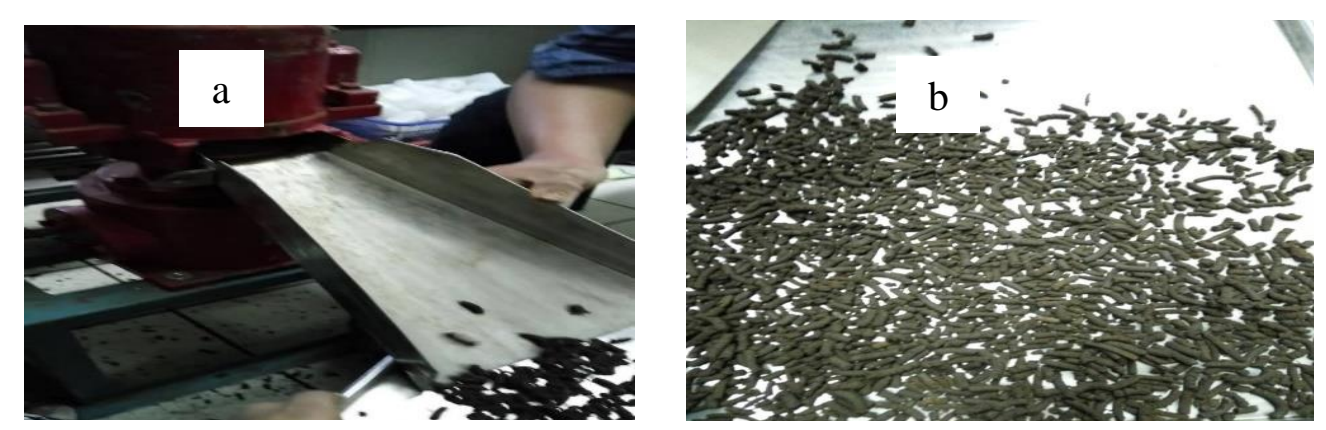

Gambar 1. Mesin pembuatan pupuk pelet (a) dan pupuk pelet yang diproduksi (b)

Pola Pelepasan Amonium $\left(\mathrm{N}-\mathrm{NH}_{4}{ }^{+}\right)$dan Nitrat 
Pola pelepasan $\mathrm{N}-\mathrm{NH}_{4}{ }^{+}$dan $\mathrm{N}_{-} \mathrm{NO}_{3}{ }^{-}$disajikan bertururt-turut pada Gambar 8 dan 9. Perlakuan pupuk pelet meningkatkan kadar $\mathrm{N}^{-} \mathrm{NH}_{4}{ }^{+}$dibandingkan dengan perlakuan kontrol sampai pada minggu 10. Pada minggu 15 kadar $\mathrm{N}-\mathrm{NH}_{4}{ }^{+}$mendekati nilai $\mathrm{N}-\mathrm{NH}_{4}{ }^{+}$perlakuan kontrol. Nilai $\mathrm{N}-\mathrm{NH}_{4}{ }^{+}$terus menurun setelah minggu 3 menuju nilai $\mathrm{N}-\mathrm{NH}_{4}{ }^{+}$perlakuan kontrol (Gambar 8).

Penurunan nilai $\mathrm{N}-\mathrm{NH}_{4}{ }^{+}$diikuti dengan kenaikan nilai $\mathrm{N}^{-\mathrm{NO}_{3}}{ }^{-}$(Gambar 9). Proses nitrifikasi dari penelitian ini dimulai pada minggu 3 , dimana proses nitrifikasi ini mengoksidasi $\mathrm{N}_{-} \mathrm{NH}_{4}{ }^{+}$menjadi $\mathrm{N}_{-} \mathrm{NO}_{3}{ }^{-}$. Pada minggu 1 sampai $7 \mathrm{~N}-\mathrm{NH}_{4}{ }^{+}$adalah bentuk $\mathrm{N}$ tersedia yang dominan.
Pada minggu 8 sampai minggu 15, $\mathrm{N}$ tersedia tanah didominasi oleh $\mathrm{N}-\mathrm{NO}_{3}{ }^{-}$.

Nilai $\mathrm{pH}$ tanah yang optimum untuk terjadinya proses nitrifikasi adalah pada $\mathrm{pH} 5.50$ (Tisdale et al., 1985). Walaupun demikian Tisdale et al. (1985) juga melaporkan bahwa nitrifikasi juga terjadi pada tanah dengan $\mathrm{pH} 3.80$. Pada percobaan ini $\mathrm{pH}$ tanah pada perlakuan pelet memiliki pH 4.09 pada minggu 3 dan naik sampai $\mathrm{pH} 4.39$ pada minggu 15. Kenaikan $\mathrm{pH}$ tanah, Ca-dd dan $\mathrm{P}$ tersedia (Hartono et al., 2016) meningkatkan proses nitrifikasi yang mentrasformasikan $\mathrm{N}-\mathrm{NH}_{4}{ }^{+}$ke $\mathrm{N}-\mathrm{NO}_{3}{ }^{-}$. Oleh karena itu pada akhir inkubasi bentuk $\mathrm{N}$ tersedia dalam bentuk $\mathrm{N}-\mathrm{NO}_{3}{ }^{-}$.

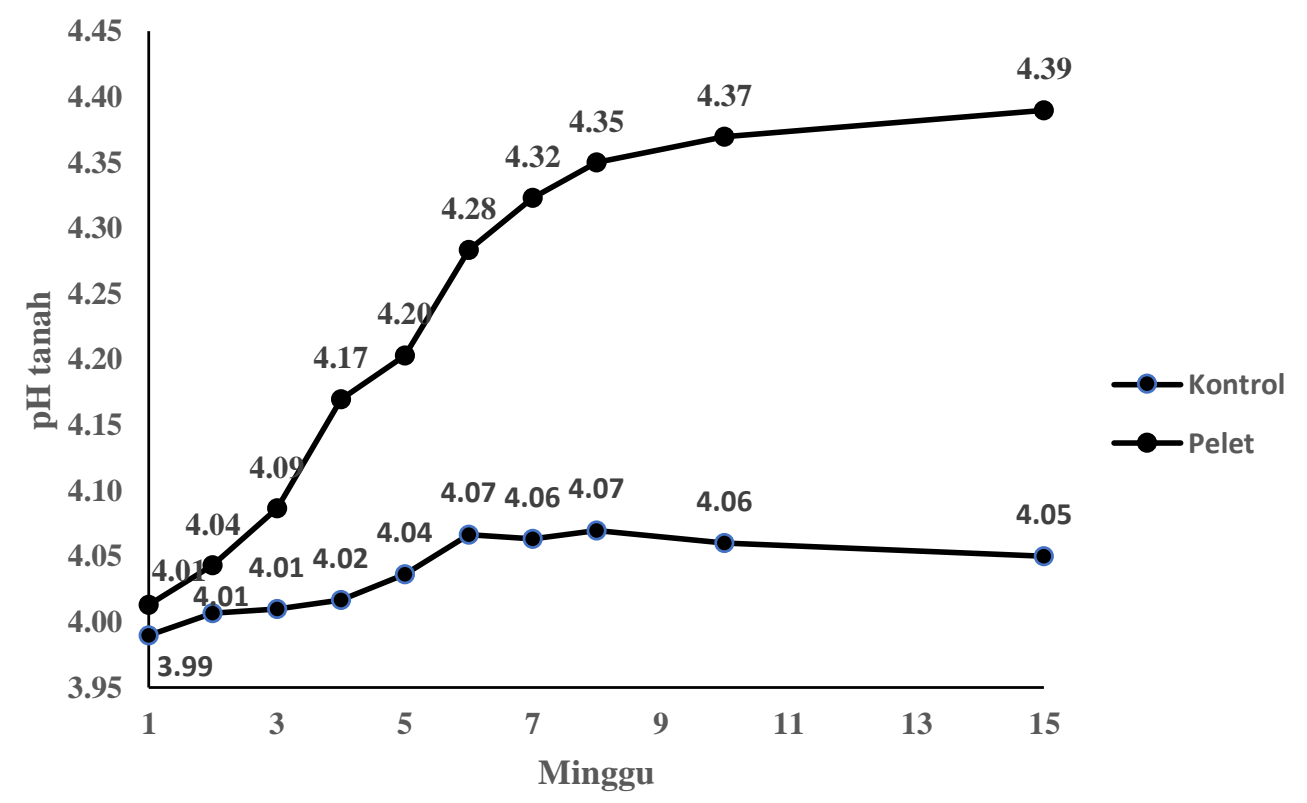

Gambar 2. Perubahan $\mathrm{pH}$ tanah pada tanah yang diberi perlakuan pupuk pellet

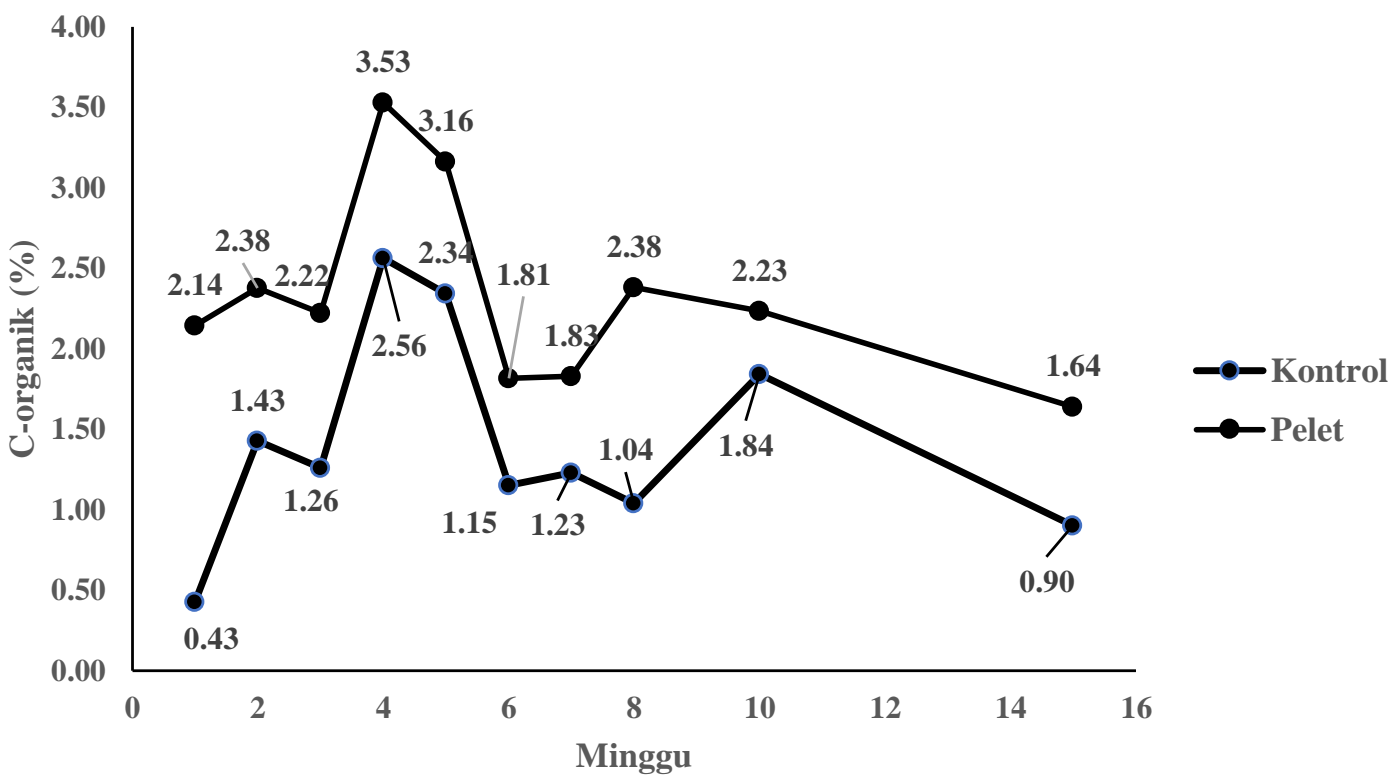

Gambar 3. Perubahan C-organik tanah pada tanah yang diberi perlakuan pupuk pelet 


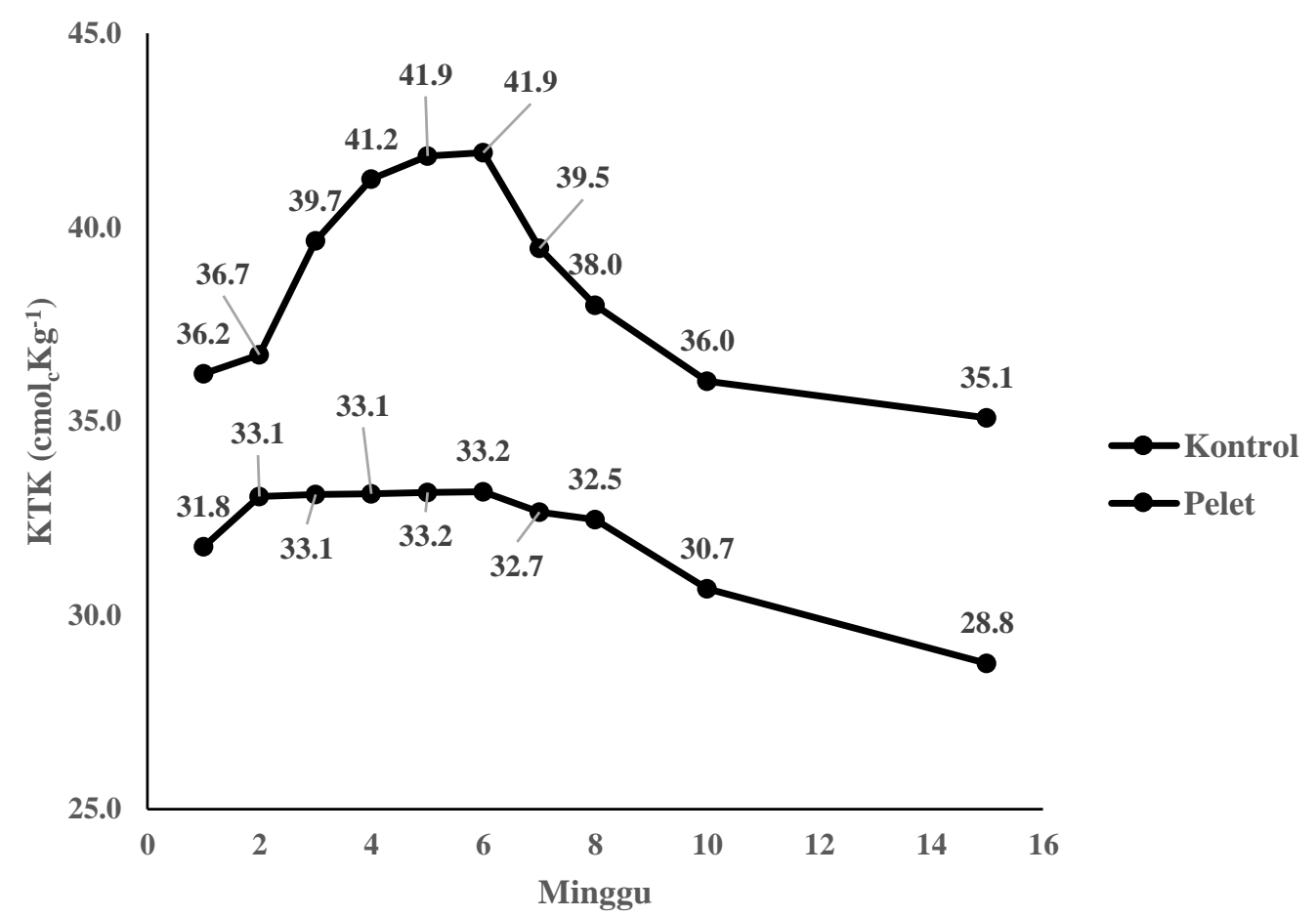

Gambar 4. Perubahan nilai KTK tanah setelah pemberian pupuk pelet

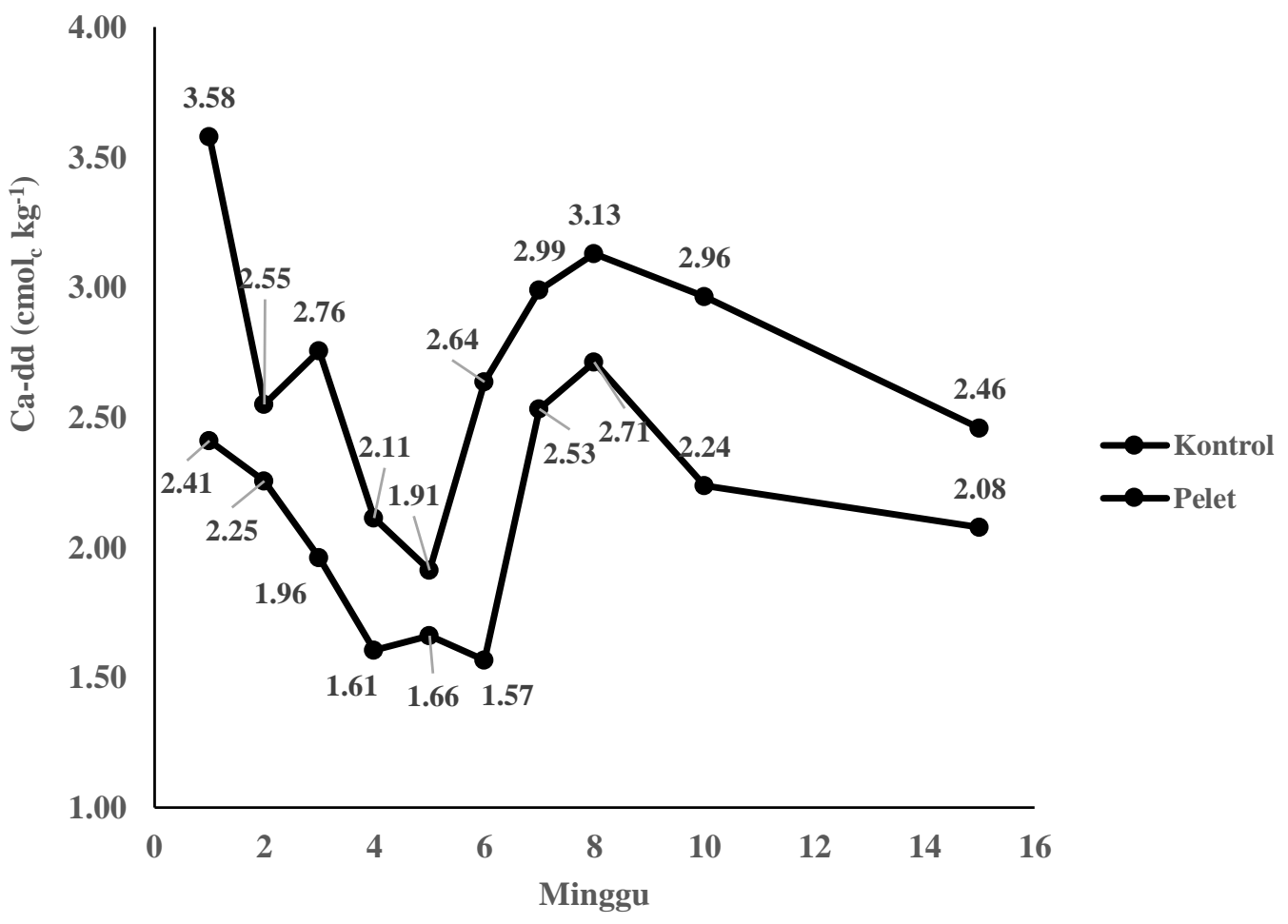

Gambar 5. Perubahan nilai Ca-dd tanah setelah pemberian pupuk pelet 


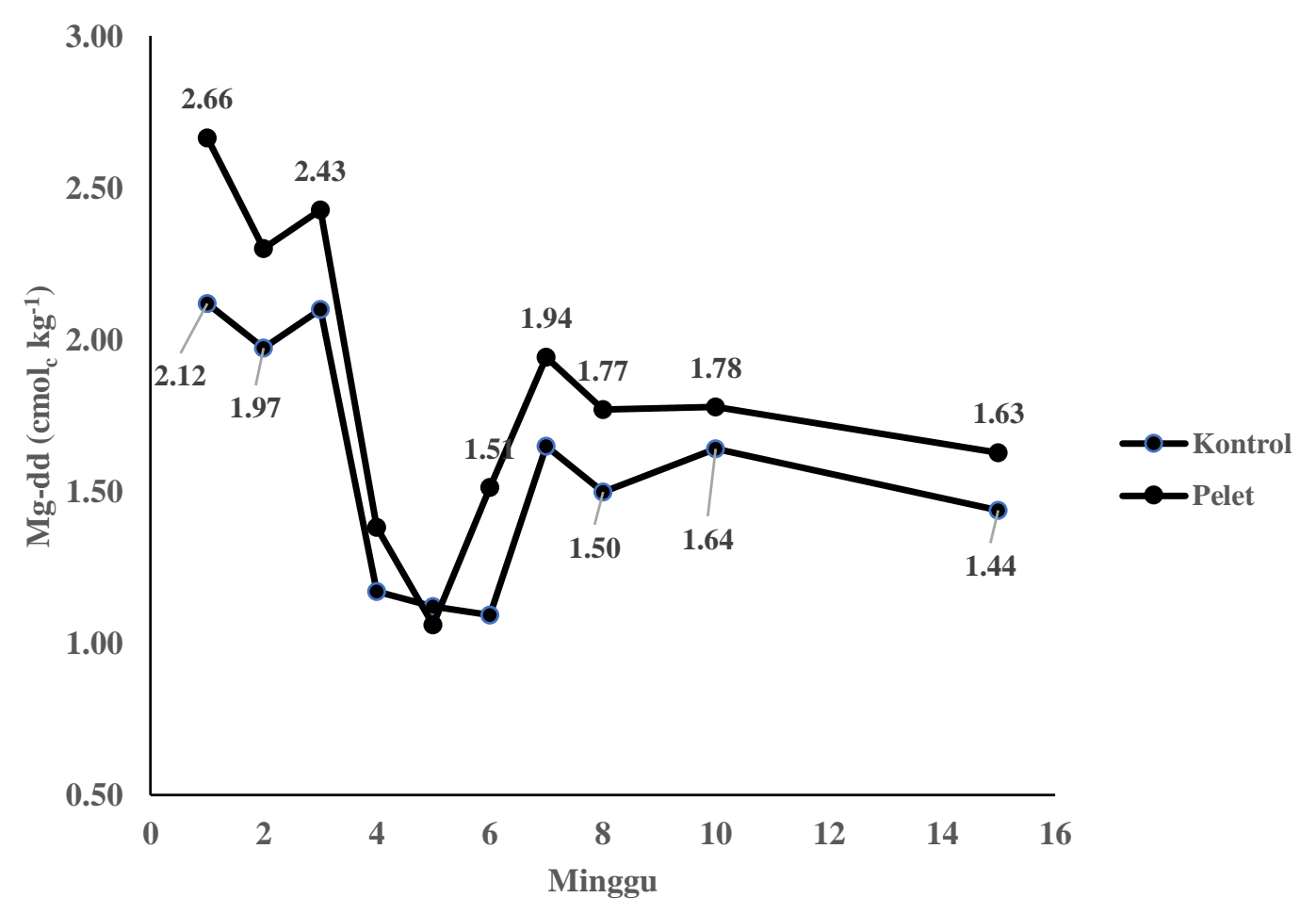

Gambar 6. Perubahan nilai Mg-dd tanah setelah pemberian pupuk pelet

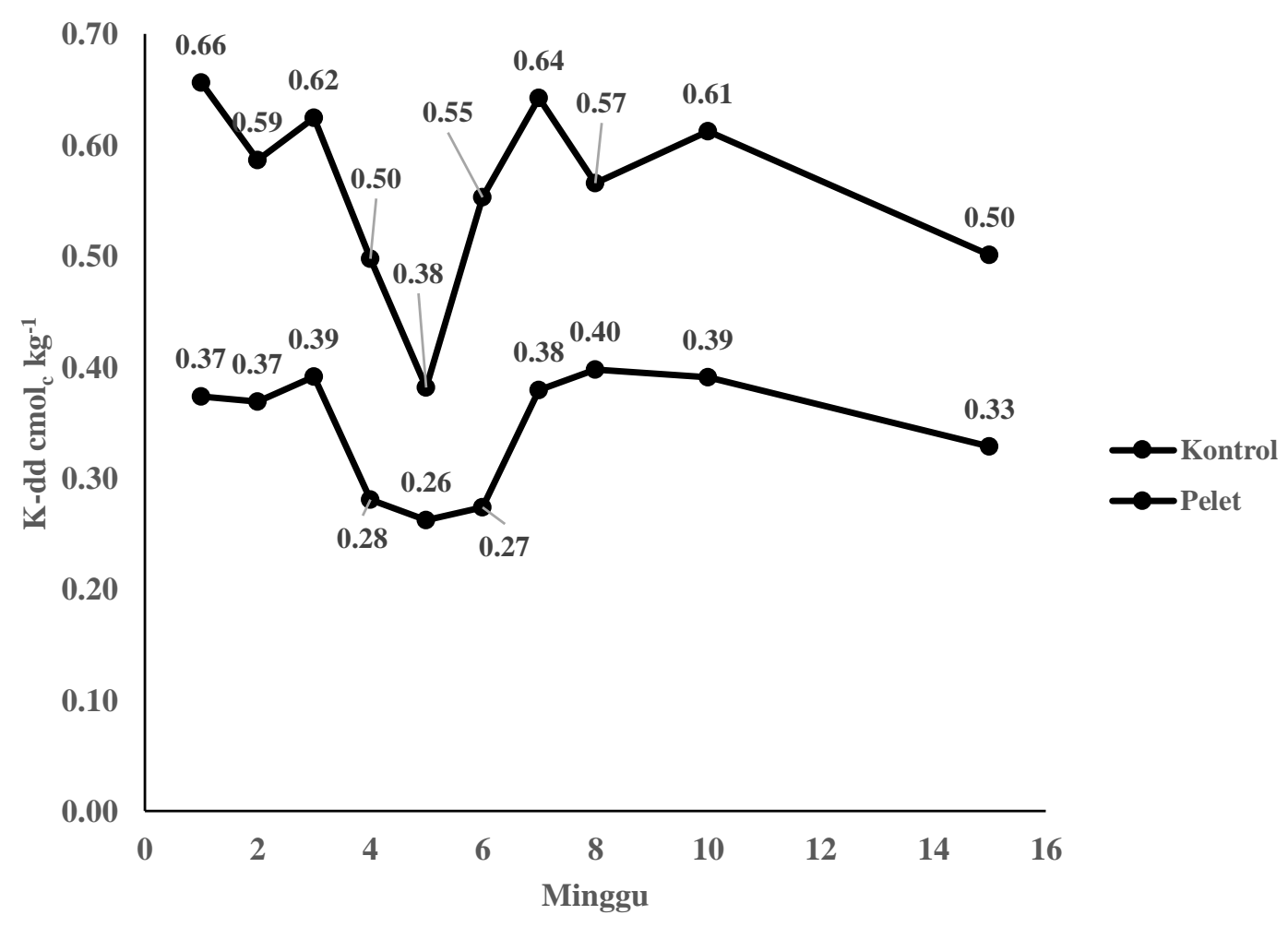

Gambar 7. Perubahan nilai K-dd tanah setelah pemberian pupuk pelet 


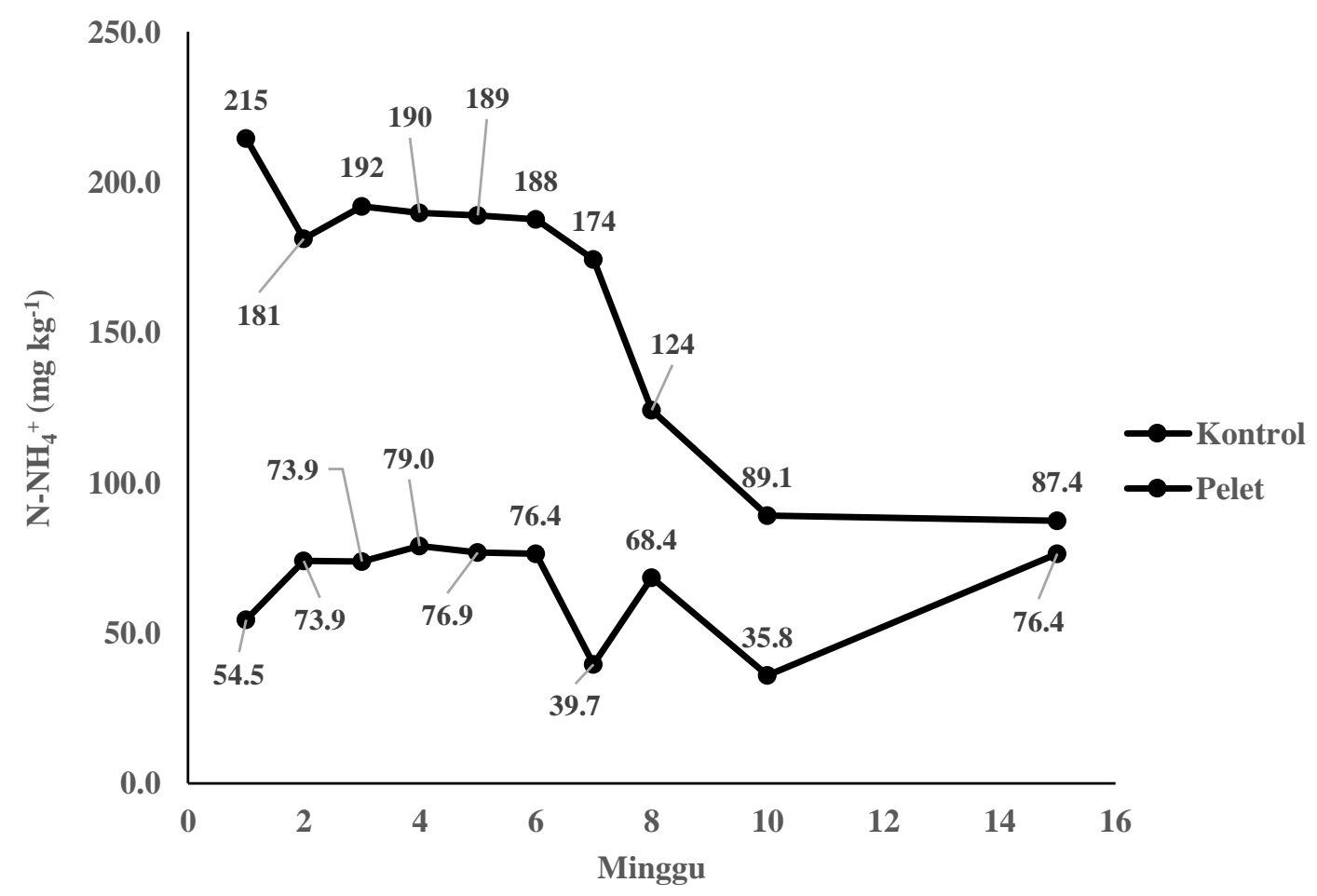

Gambar 8. Perubahan nilai $\mathrm{N}-\mathrm{NH}_{4}{ }^{+}$tanah setelah pemberian pupuk pelet

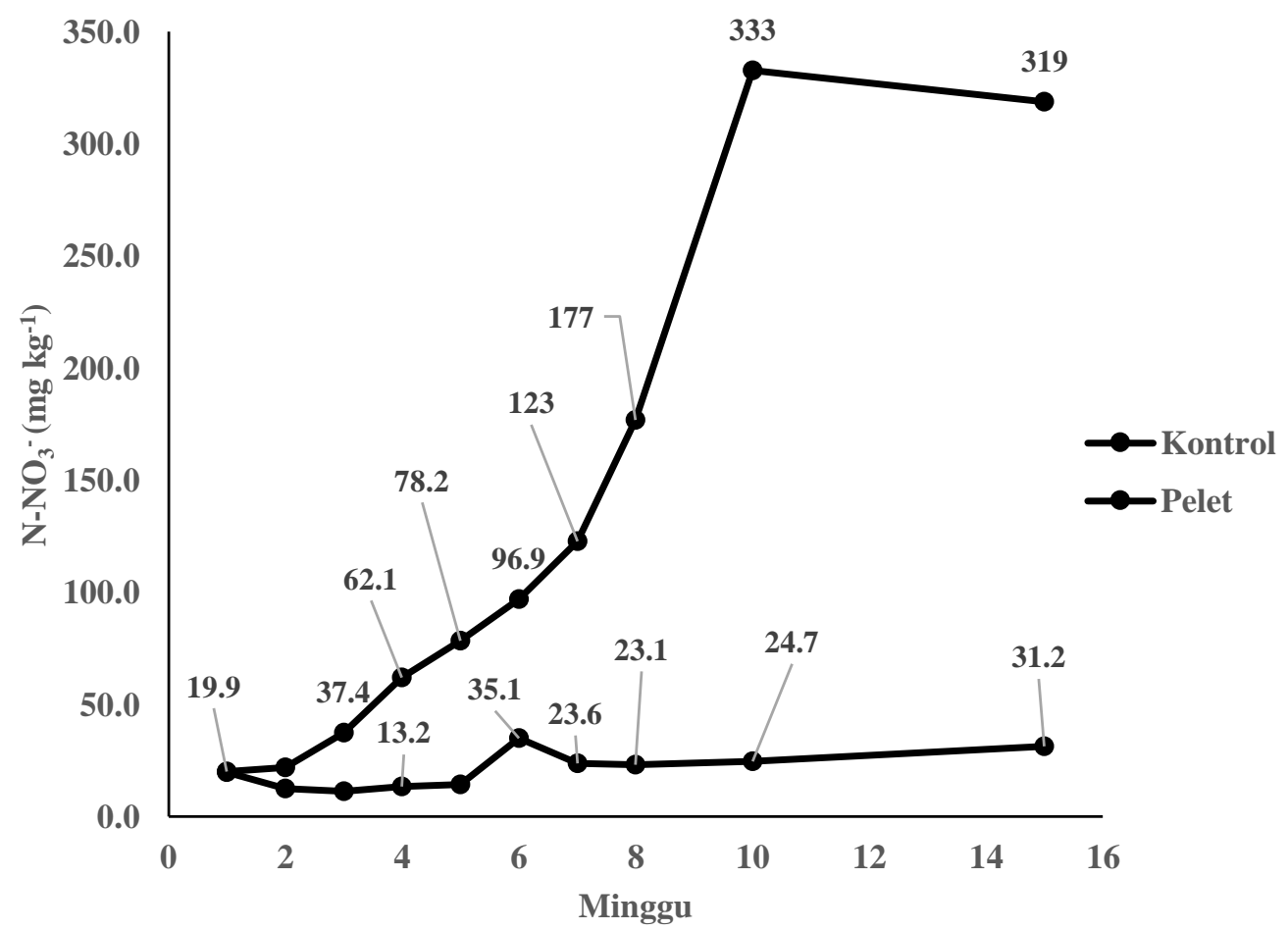

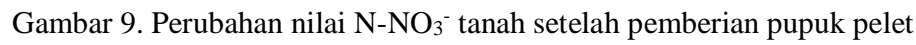




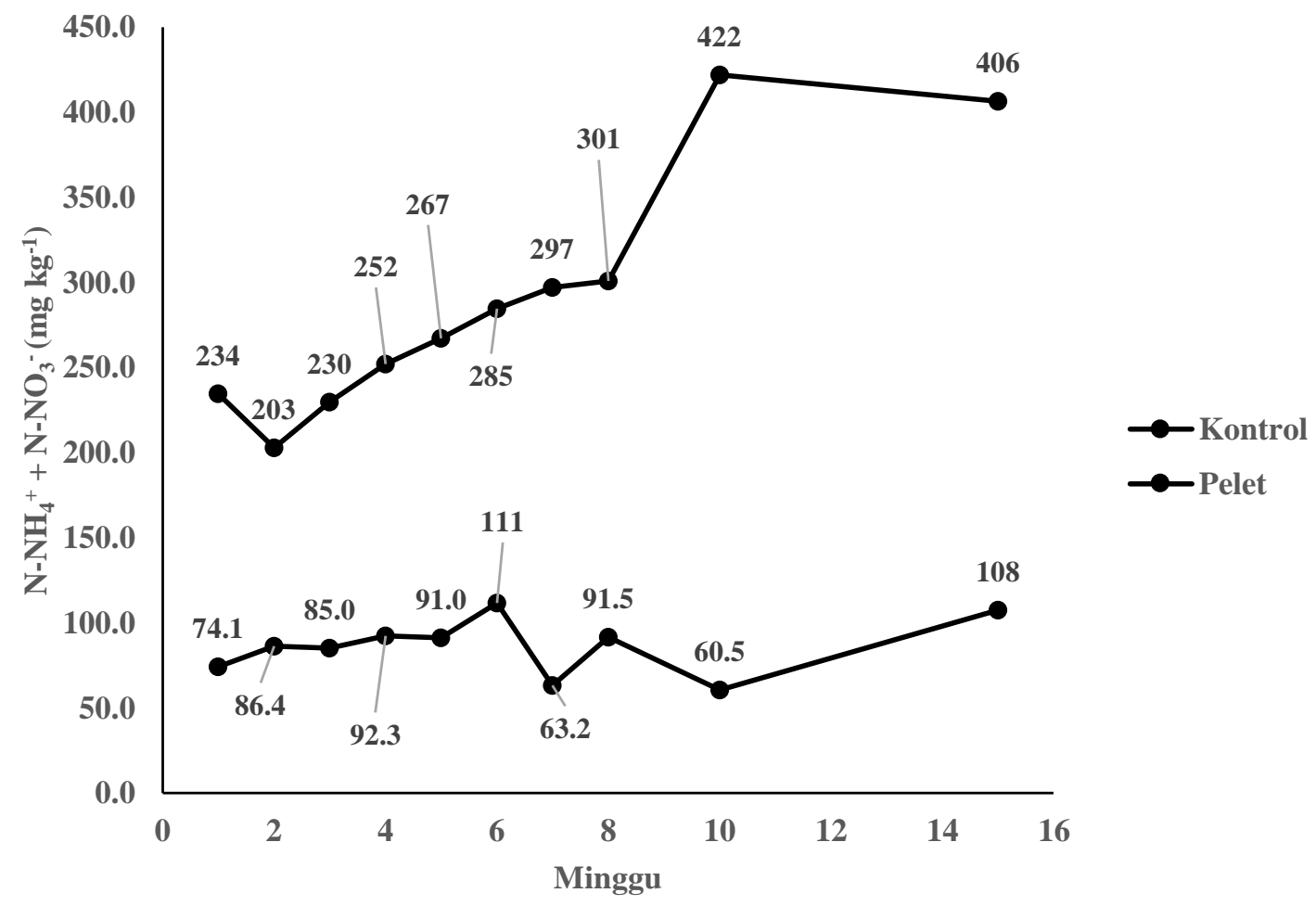

Gambar 10. Perubahan $\mathrm{N}-\mathrm{NH}_{4}{ }^{+}+\mathrm{N}^{-\mathrm{NO}_{3}}{ }^{-}$(N-tersedia) setelah pemberian pupuk pelet

Evaluasi penyediaan $\mathrm{N}$-tersedia disajikan pada Gambar 10. N-tersedia adalah penjumlahan $\mathrm{N}_{-} \mathrm{NH}_{4}{ }^{+}+\mathrm{N}-$ $\mathrm{NO}_{3}{ }^{-}$karena kedua bentuk $\mathrm{N}$ ini adalah bentuk-bentuk $\mathrm{N}$ yang diperlukan oleh tanaman.

Pada Gambar 10 dapat dilihat bahwa pada perlakuan pelet, $\mathrm{N}$-tersedia meningkat sampai pada minggu 10. Setelah minggu 10, N-tersedia mulai menurun. Pada perlakuan kontrol $\mathrm{N}$-tersedia pada tiap masa inkubasi cenderung tetap.

Perubahan kadar N-tersedia pada perlakuan pelet menunjukkan bahwa pupuk pelet dapat menyediakan $\mathrm{N}$ tersedia pada masa-masa pertumbuhan tanaman. Masa pertumbuhan tanaman pangan umumnya sekitar 3 bulan. Sampai pada masa inkubasi 15 minggu (sekitar 4 bulan) kadar N-tersedia tanah yang diberi perlakuan pupuk pelet sekitar 4 kali kadar N-tersedia tanah perlakuan kontrol. Hal ini menunjukkan bahwa pemberian pupuk pelet dapat meningkatkan $\mathrm{N}$-tersedia.

\section{SIMPULAN}

Pupuk pelet dengan bahan dasar lumpur kolam ikan yang diperkaya dengan pukan kambing dan air kolam ikan meningkatkan $\mathrm{pH}$ tanah, C-organik, KTK tanah, Cadd, $\mathrm{Mg}$-dd, $\mathrm{K}-\mathrm{dd}, \mathrm{N}-\mathrm{NH}_{4}{ }^{+}$dan $\mathrm{N}_{-} \mathrm{NO}_{3}{ }^{-}$.

Pola pelepasan $\mathrm{N}$ tersedia menunjukkan bahwa pupuk pelet bisa menyediakan $\mathrm{N}_{-} \mathrm{NH}_{4}{ }^{+}$dan $\mathrm{N}-\mathrm{NO}_{3}{ }^{-}$. Walaupun demikian terjadi proses nitrifikasi yang mengubah $\mathrm{N}_{-} \mathrm{NH}_{4}{ }^{+}$menjadi $\mathrm{N}-\mathrm{NO}_{3}{ }^{-}$. Oleh karena itu $\mathrm{N}-$ $\mathrm{NO}_{3}{ }^{-}$adalah bentuk yang dominan pada tanah yang diberi pupuk pelet.

Pupuk pelet dapat menyediakan sekitar 4 kali N-

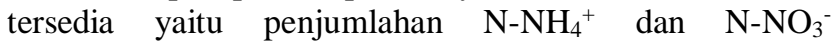

dibandingkan dengan tanah kontrol pada masa akhir inkubasi.

Pupuk pelet berbahan dasar lumpur kolam ikan mempunyai potensi untuk dikembangkan di desa-desa yang melakukan pertanian terpadu dengan perikanan dan peternakan. Pupuk pelet dapat mengurangi dosis pupuk urea konvesional, oleh karena itu perlu diteliti lebih lanjut berapa persen pupuk urea konvensional yang dapat digantikan oleh penggunaan pupuk pelet ini.

\section{DAFTAR PUSTAKA}

Bohn. H.L, B. L. Mc Neal, and G.A.O. Connor. 1979. Soil Chemistry. John Willey \& Sons. 155-171pp. New York

Escobar, M.E.O. dan N.V. Hue. 2008. Temporal changes of selected chemical properties in three manure amended soils of hawaii. Bioresource Technology, 99:8649-8654.

Follet, R.F., E.A. Paul, and E.G. Pruessner. 2017. Soil carbon dynamics during a long-term incubation study involving ${ }^{13} \mathrm{C}$ and ${ }^{14} \mathrm{C}$ measurements. Soil Sci., 172:189-208.

Gulser, C., Z. Demir Z and I.C. Serkan. 2010. Changes in some soil properties at different incubation periods after tobacco waste application. J. of Environ. Biology, 31(5):671-674.

Hartono, A., K. Yokota, and T. Baba. 2012. Survey of water quality and soil fertility of fresh water fish cultivation ponds in Bogor, Indonesia. Regional 
Workshop Water, Land and Southeast Asia Food Sovereignty. 41 p. Bogor

Hartono A, K. Yokota, T. Baba and B. Subroto. 2016. Changes in some soil chemical propertis and production of sweet potato, Ipomoea batatas (L.) lam, treated with fishpond sediment and water in Petir Village, Dramaga, Bogor, Indonesia. J. ISSAAS, 22(2):1-9.

Roy, S. and Md.A. Kashem. 2014. Effects of organic manures in changes of some soil properties at different incubation periods. Open Journal of Soil Science, http://dx.doi.org/10.4236/ojss.2014.43011

Santari P.T., A. Hartono dan Suwarno. 2018. Pengaruh pemberian pelet dari lumpur kolam ikan dan kotoran kambing pada pertumbuhan dan produksi jagung manis. Jurnal Ilmu Pertanian, 24(1):41-47.

Soepratohardjo, M., H. Subagjo, Suhardjo, Ismangun, D.S. Marsoedi, A. Hidayat, Y. Dai, A. Adi, M. Supartini, Mursidi and J.S. Adiningsih. 1983.
Terms of reference survey of soil capability. Center for Soil Research, (In Indonesian). 52 p. Bogor

Tisdale, S.L., W.L. Nelson and J.D. Beaton. 1985. Soil Fertility and Fertilizers, $4^{\text {th }}$ ed. Macmillan Publishing, New York. Pp189-569.

Tungka, W.A., H. Haeruddin dan C. Ain 2016. Konsentrasi nitrat dan ortofosfat di muara sungai banjir kanal barat dan kaitannya dengan kelimpahan fitoplankton Harmful Alga Blooms (HABs). Saintek Perikanan, 12(1):40-46.

Widowati, R.L, D.S. Neve, Sukristiyonubowo, D. Setyorini, A. Kasno, I.A. Sipahutar and Sukritiyohastomo. 2011. Nitrogen balances and nitrogen use efficiency of intensive vegetable rotations in south east asian tropical andisols. Nutr $\mathrm{Cycl}$ Agroecosyst., 91:131-143. 